\title{
AGAMA DALAM PERSPEKTIF SOSIOLOGIS
}

\author{
Syaiful Hamali \\ Universitas Islam Negeri RadenIntan Lampung \\ syaifulbamali@radenintan.ac.id
}

\begin{abstract}
In established societies, religion is an important social institutional structure, which complements all existing social systems and is interdependent with other parts, so that changing one part will affect other parts, ultimately affecting the entire social system in society. Sedamgkan religion is related to trust and its various problems to date have always been found in every society, including providing meaning, meaning and interpretations by scientific experts on social order in religious communities. Religion is marked as unifying the most sublinest buman aspirations; as a sign of morality, as a source of community order and individual peace; as something that glorifies and makes human beings civilized. On the other hand religion is accused of being a barrier to progress, and heightens fanaticism and is intolerant, hostile, superstitious, heresy, and khurafat. But religion also shows its ability to give birth to very revolutionary tendencies in the fabric of people's lives, such as the 19th-century peasant uprising in Germany as a milestone in the early rise of human civilization.
\end{abstract}

\section{Abstrak}

Dalam masyarakat yang sudah mapan, agama merupakan salah satu struktur institusional sosial yang penting, yang melengkapi selurub sistem sosial yang ada dan saling tergantung dengan bagian lainnya, sehingga perubahan salab satu bagian akan mempengarubi bagian lain, pada akbirnya mempengarubi selurubi sistem sosial dalam masyarakat. Sedamgkan agama menyangkut kepercaayaan dengan berbagai permasalahannya sampai saat ini senantiasa ditemukan dalam 
setiap masyarakat, termasuk memberikan arti, makna dan interpretasiinterpretasi oleh para abli ilmu pengetahuan tentang tatanan sosial dalam masyarakat agama. Agama di tandai sebagai pemersatu aspirasi manusia yang paling sublin; sebagai tanda moralitas, sebagai sumber tatanan masyarakat dan perdamaian bahtin individu; sebagai sesuatu yang memuliakan dan yang membuat manusia beradab. Di sisi lain agama dituduh sebagai penghambat kemajuan, dan mempertinggi fanatisme dan bersifat intoleran, permusuban, tahayul, bid'ah, dam khurafat. Tetapi agama juga memperlihatkan kemampuannya melahirkan kecenderungan yang sangat revolusioner dalam tatanan kehidupan masyarakat, seperti peristiwa pemberontakan petani abad ke 19 di Jerman sebagai tonggak sejarah awal kebangkitan peradaban umat manusia.

Keywords: Religion, Perspective, Sociology

\section{A. Pendahuluan}

Agama disebut sebagai berwajah ganda bukanlah sebuah pernyataan yang tidak beralasan, disebabkan keberadaan agama itu sendiri dalam masyarakat mempunyai dua fungsi. Pertama, agama telah memajukan peradaban manusia, dengan menghormati kehidupan, menjunjung tinggi nilai-nilai kemanusian yang universal, dan mencintai hak-hak asasi manusia, tetapi di sisi lain agama telah menimbulkan perpecahan, konflik, peperangan, dan permusnahan diantara manusia. Kedua, agama telah mempersatukan komunitaskomunitas ke dalam kelompok-kelompok, tetapi di sisi lain juga agama mempertinggi perbedaan dari kelompok-kelompok lain bahkan menimbulkan konflik social dikalnangan masyarkat.

Setiap penganut agama mempercayai bahwa agama yang dianutnya adalah agama yang paling benar, dan mereka berusaha menyebarluaskan kepercayaannya sebagai sebuah kebenaran, sistem penyampaian kepercayaan itu kadang-kandang menimbulkan berbagai bentuk ketegangan di tengah-tengah masyarakat yang pluralistik. Hal ini menandakan bahwa agama termasuk kedalam konstruksi sosial yang harus dipelihara dan dilestarikan.

Kepecayaan terhadap wujud Tertinggi diberi bentuk pengungkapan yang berbeda-beda oleh setiap penganut agama. Perspektif orang yang agamais mendasarkan pada keimanan, sedangkan perspektif sosiolog didasarkan pada data empiris. 
Karakteristik perspektif sosiologi memiliki dua bentuk utama. Pertama, bersifat empiris, dalam studi sosiologi tentang agama berupaya mendasarkan interpretasi-interpretasinya pada data. Penjelasan mereka tentang kenyataan sosial didasarkan pada pengalaman-pengalaman kongkrit. Kedua, bersifat objektif bahwa interpertaasi-interpretasi mereka tentang agama berdasarkan data yang ada (das sein) dan bukan menurut apa yang seharusnya (das sollen). Perspektif kedua ahli itu tidak dapat mewakili pandangan yang menyeluruh tentang agama, kecuali bila ada pengitegrasian antara pemikiran dengan nilai-nilai kebenaran kedua sumber tersebut. Selanjutnya, tulisan ini mencoba membicarakan tentang pandangan tokoh-tokoh sosiologi tentang keberadaan agama dalam masyarakat.

\section{B. Agama Dasar Kehidupan Masyarakat}

Agama dalam pandangan sosiologi merupakan pandangan hidup yang yang harus diterapkan dalam kehidupan masyakat. Keduanya mempunyai hubungan saling mempengaruhi dan saling bergantung antara satu bagian dengan bagian lainnya. Diamping itu agama turut pula membentuk struktur sosial dalam masyarakat. Dadang Kahmat menjelaskan bahwa; Adapun agama dalam pengertian sosiologi adalah gejala sosial yang umum dan dimiliki oleh seluruh masyarakat yang ada di dunia ini tanpa kecuali. Ia merupakan salah satu aspek dalam kehidupan sosial dan bagian dari sistem sosial suatu masyarakat. Agama juga bisa dilihat sebagai unsur dari kebudayaan suatu masyarakat di samping unsur-unsur yang lain. ${ }^{1}$

Agama adalah sesuatu yang bersifat sangat pribadi, karena penghayatan yang bersifat pribadi itu, kadang-kadang agama sulit dianalisa dengan menggunakan perspektif sosiologis yang selalu bersifat sosial. Memang benar bahwa agama di satu sisi bersifat individual, tetapi di pihak lain dia juga bersifat sosial. ${ }^{2}$ Sosiologi agama sebagai dasar kehidupan masyarakat memungkinkan lahirnya sikap toleransi, dan setiap individu menghargai dan menghormati

1 Dadang Kahmad, Sosiologi Agama, (Bandung: PT.Remaja Rosdakarya, Cet.V, 2009), h. 14.

2 Bernard Raho SVD, Agama Dalam Perspektif Sosiologis, (Jalarta: Penerbit Obor, Cet. I, 2003, h. 2. 
pendapat serta aktivitas yang dilakukan oleh kelompok yang berbeda agama atau kepercayaannya, perbedaan sikap ini dikenal dengan istilah toleransi. Dalam bingkai toleransi diletakan dasar-dasar kehidupan masyarakat yang berbentuk pluralis, demokrasi, dan keadilan sosial bagi masyarakat. Selain dari itu, tertanamnya sikap toleransi pada diri individu akan memberikan kebebasan kepada masyarakat untuk memperoleh hak-haknya, saling menghormati, dan mengakui keberadaan mereka, sehingga mereka diberikan kesempatan untuk hidup berdampingan.

Dalam masyarakat yang sudah mapan, agama merupakan salah satu struktur institusional penting yang melengkapi keseluruhanan sistem sosial. Agama merupakan suatu kekuatan yang berpengaruh di dalam kehidupan manusia. Agama memancarkan nilai-nilai atau jiwa keagamaan pada pemeluknya, kondisi masyarakat yang menadasarkan nilia-nilai agama dalam kehidupannya dalam psikologi dkenal dengan istilah psikologi agama.

Psikologi agama sebagai ilmu terapan (applied science) mempelajari pengaruh kepercayaan terhadap sikap dan tingkah laku atau mekanisme yang bekerja dalam diri indvidu, karena cara berfikir, bersikap, dan bertingkah laku tidak bisa dipisahkan dari keyakinannya. Karena keyakinan itu termasuk ke dalam konstruksi kepribadian, yang tercermin dalam kehidupan bermasyarakat dan berbangsa. Psikologi agama mempelajari tentang kesadaran agama (religious counsioness), yaitu sesuatu yang hadir (terasa) dalam fikiran manusia dan dapat juga dikatakan bahwa ia adalah aspek mental dan aktivitas manusia beragama. Sedangkan pengalaman agama (religious experience) adalah unsur perasaan dalam kesadaran agama, yaitu perasaan yang membawa seseorang kepada keyakinan yang dihasilkan oleh tindakan atau amaliah yang dilakukan setiap hari, sebagai bagian dari aspek keagamaan.

Dalam sejarah tercatat bahwa kehidupan masyarakat Islam di Madinah al-Munawarah didasarkan kepada agama, dimana nabi Muhammad Saw memulai dengan menanamkan nilai-nilai Tauhid kepada masyarakatnya dengan cara mendirikan masjid Quba, sebagai mesjid pertama didirikan Nabi Muhammad Saw tempat beribadah dan sarana kegiatan-kegiatan sosial kemasyarakatan, kemudian nabi membentuk hubungan siraturrabim antara kaum Anshor dengan kaum Mubajirin dan mengadakan perjanjian Madinah 
dalam konteks sekarang lebih dikenal dengan sebutan masyarakat Madani. $^{3}$

Intelektual muslim kontemporer berusaha memformulasikan nilai-nilai agama dalam mengembangkan masyarakat madani sebagai landasan operasional dalam bersikap, dan bertindak bagi setiap individu. Masyarakat madani hidup dan berkembang dalam lingkungan masyarakat yang beradab, berbudi luhur, berakhlak mulia, egalitarianisme dan menghargai seseorang berdasarkan prestasi kerja

Tim ICCE UIN Jakarta mengutip pendapat AS Hikam bahwa dalam tradisi Eropa (sekitar pertengahan abad XVIII), pengertian civil society dianggap sama dengan pengertian negara (state), yakni suatu kelompok/ kekuatan yang mendominasi kelompok masyarakat lainnya, Akan tetapi pada paruh abad XVIII terminologi ini mengalami pergeseran makna. State dan civil society dipahami sebagai dua buah ententitas yang berbeda, sejalan dengan proses pembentukan sosial (social formation)dan perubahan strukur politik di Eropa sebagai pencerahan (enlightenment) dan modernisasi dalam menghadapi persoalan dunia. ${ }^{4}$

Sedangkan istilah masyarakat madani sering juga dipakaikan untuk masyarakat sipil (civil society). .Namun dikalangan cendikiawan Muslim berusaha membedakan antara masyarakat madani dengan civil society Sebagaimana dijelaskan Nurcholis Madjid bahwa masyarakat Madani merupakan masyarakat yang dibentuk dengan landasan motivasi dan etos keagamaan, dan menjadikan agama sebagai kriteria masyarakat yang berperadab (masyarakat madani). Civil society dalam konteks masyarakat Barat, lebih kepada aspek

${ }^{3}$ Kiki Muhamad Hakiki dan Zaenal Muttaqien, Konflik dan Integrasi Sosial (Telaab Buku A. Malik. MTT berjudul "Pura dan Masjid; Konflik dan Integrasi Pada Suku Tengger Jawa Timur), Al-AdYaN/Vol. IX, N0. 2/Juli-Desember/2014, h. 50

${ }^{4}$ Tim ICCE UIN Jakarta, Pendidikan Kewargaan (civic Education) Demokrasi, Hak Asasi manusia \& Masyarakat Madani, Jakarta: Pernada Media, Edisi Revisi, 2003), h. 238 
politik dan perlindungan hukum dari hubungan yang berbenturan antara negara disatu pihak dengan warga negara di lain pihak.

Ahmad Baso dalam Nurcholis Madjid menulis bahwa: Cendekiawan Muslim Indonesia menarik wacana civil society ke dalam konteks sejarah Islam, karena keyakinan mereka bahwa tradisi Islam juga memiliki perjalanan historis mengenai hal terebut. Dasar-dasar masyarakat beradab yang telah dimiliki Bani Abbasiyah, kemudian dikembangkan oleh para khalifah yang bijaksana (al-Khalifah ArRasyidin). ${ }^{6}$

Dawam Raharjo mendefinisikan masyarakat madani adalah masyarakat yang mengacu kepada nilai-nilai kebijakan umum yang disebut al-Khair. Masyarakat seperti itu harus dipertahankan dengan bentuk persekutuan, perkumpulan, perhimpunan atau assosiasi yang memiliki missi dan praktek. ${ }^{7}$ Pada kesempatan lain, Dawam mengutip pendapat Anwar Ibrahim bahwa dalam masyarakat madani mengandung tiga hal, yaitu; agama sebagai sumber peradaban, sebagai posisinya, dan masyarakat kota adalah hasilnya seperti yang pernah dicontohkan nabi Muhammad Saw dalam membangun masyarakat Madinah melalui sebuah perjanjian yang dikenal dengan perrjanjian Madinah. $^{8}$ Dalam pandangan sosiologis masyarakat madani yang dibangun Nabi Muhammad Saw selalu mendasarkan aktiivitasnya kepada nilai-nilai agama sebagai pedoman dalam kehidupan bermasyarakat dan bernegara.

Dalam perspekktif sosiologis, agama dipandang sebagai sistem kepercayaan yang diwahyukan dalam perilaku sosial tertentu dalam masyarakat, setiap perilaku yang dijalaninya selalu berhubungan dengan sistem keyakinan dari ajaran agama yang dianutnya. Perilaku individu dan nilai-nilai sosial digerakkan oleh kekuatan dari dalam yang didasarkan pada nilai-nilai ajaran agama yang menginterlisasi sebelumnya dan kandangkala kepercayaan sepeti ini membawa sukbektifias dalam beragama. Dadang Kahmad

Nurcholis Madjid, Kehampaan Spiritual Masyarakat Modern, Jakarta: Penerbit Mediacita, 2000), Cet. I, h. 3

6 Nurcholis Madji, Civil Society Versi Masyarakat Madani, (Bandung: Pustaka Hidayah, 1990), h. 21.

7 M.Dawam Raharjo, Masyarakat Madani: Agama Kelas Menengah dan Perubahan Sosial, (Jakarta: LP3ES), h. 52.

8 Ibid, h. 145. 
menuls bahwa karena itu Wach lebih jauh beranggapan bahwa keagamaan yang bersifat subjektif, dapat diobjektifkan dalam berbagai macam ungkapan, dan ungkapan-ungkapan tersebut mempunyai struktur tertentu yang dapat difahami. ${ }^{9}$

Lebih jauh Kahmad menjelaskan bahwa ketika mengungkap hubungan interdipendensi antara agama dan masyarakat, Wach menunjukkan adanya pengaruh timbal balik antara kedua faktor tersebut. Pertama, pengaruh agama terhadap masyarakat, seperti ysng terlihat dalam pembentukan, pengembangan, dan penentuan kelompok keagamaan spesifik yang baru. Kedua, pengaruh masyarakat terhadap agama. Dalam hal ini, Wach memusatkan perhatiannya pada faktor-faaktor sosial yang memberikan nuansa dan keberagaman perasaan dan sikap keagamaan yang terdapat dalam suatu lingkungan atau kelompok sosial tertentu. ${ }^{10}$

\section{Tipologi Masyarakat dan Agama}

Dalam masyarakat agama, bentuk kepercayaan merupakan sesuatu yang bersifat sentral dalam kehidupan manusia, dan setiap tingklah laku dan perbuatan mereka hubungkan dengan sesuatu yang bersifat transendental dalam hidup ini. Agama menawarkan hubungan melalui pemujaan dan upacara-upacara peribadatan, karena memberikan rasa emosional bagi rasa aman baru dan identitas yang lebih kuat ditengah-tengah ketidakpastian dan ketidakmungkinan bagi kehidupan manusia

Dalam perspektif sosiologis, agama dipandang sebagai sistem kepercayaan yang diwujudkan dalam perilaku sosial yang terdapat dalam masyarakat. Disamping itu agama berkaitan dengan pengalaman manusia, baik sebagai individu maupun kelompok Dan setiap peran yang lakukan pribadi ata kelompok selalu terkait dengan sistem keyakinan dari ajaran agama yang dianutnya, perbauatn dan sikap yang dilakukan indvidu didasarkan pada nilai-nilai agama yang telah terinternalisasikan sebelumnya.

2009, h. 53.

${ }^{9}$ Dadang Kahmad, Sosiologi Agama,Bandung: PT.Remaja Rosdakarya, Cet.V,

10 Ibid, h. 54. 
Keberagamaan seseorang memiliki pengaruh yang kuat terhadap perilaku masyarakat yang bersumber pada emosi keagamaan. Maka ditemuilah berbagai bentuk persepsi masyarakat terhadap agama. Setiap masyarakat mempunyai pola dan tingkah laku keagamaan yang berbeda Elizabeth K.Nottingham, sosiolog agama, membagi tipologi masyarakat dan agama/ sakral dalam beberapa entuk, yaitu :

1. Tipologi Masyarakat yang Terbelakang dan Nilai-Nilai Sakral. Masyarakat-masyarakat yang mewakili tipe ini dijelaskan Elizabeth, bahwa; Tingkat perkembangan teknik mereka masih rendah dan pembagian kerja atau pembidangan kelas-kelas sosial relatif masih kecil. Keluarga adalah lembaga mereka yang paling penting dan spelisasi pengorganisasian kehidupan pemerintahan dan ekonomi masih amat sederhana. Laju pertumbuhan sosial masih lambat. ${ }^{11}$

Pada tipe ini pembagian tugas belum ada, dimana seorang kepala desa merangkap sebagai tokoh agama, pemuka masyarakat, tokoh adat, juga seorang dukun, dan penentu dalam pertanian, serta jumlah anggota masyarakatnya masih sedikit, namun rasa kekeluargaannya sangat kental, mereka sering bertemu dan berbicang-bicang bila mereka mendapat kesulitan. Selanjutnya, pengembangan tradisi-tradisi yang ada dalam masyarakat hanya melalui berita dari mulut ke mulut anggota masyarakat, ini disebabkan rendahnya tingkat tulis baca. Bagi individu agama menjadi landasan dalam proses sosialisasi. Hal ini ditandai dengan dilaksanakannya upacara-upacara keagamaan. Misalnya pada peristiwa kehamilan, kelahiran, ketika seseorang memasuki usia remaja, peristiwa kematian dan peristiiwa-peristiwa lainnya. Pada tipe ini agama dan nilai-nilai yang sakral memiliki peranan yang dominan dan menentukan dalam kehidupan masyarakat.

Elizabeth berkesimpulan bahwa ada dua masalah pokok dalam masyarakat tipe ini, yaitu; Pertama, agama memasukkan pengaruhnya yang sakral ke dalam sistem nilai-nilai masyarakat secara mutlak; Kedua, dalam keadaan lembaga lain selain keluarga, relative belum berkembang, agama jelas menjadi fokus utama bagi

11 Elizabeth K,Nottingam, Religion And Society, ter, Adbul Muis Naharong, (Jakarta : CV. Rajawali, Cet. I, 1985), h. 51 
pengintegrasian dan persatuan dari masyarakat secara keseluruhan. ${ }^{12}$ Nilai-nilai agama seringkali menimbulkan dan meningkatkan sikap konservatisme dalam menghalangi perubahan-perubahan kehidupan sosial masyarakat, seolah-olah agama turut menghambat kemajuan. Dalam tipe ini kedudukan agama sangat kuat sekali, segala sesuatu mereka ukur dengan aturan-aturan dan ketentuan agama.

Kedudukan agama bagi masyarakat turut memberikan bentuk pada keseluruhan proses sosialisasi individu yang ditandai dengan diadakan upacara-upacara keagamaan pada saat kematian, kelahiran, masa perkawinan, masa anak-anak, masa remaja, masa dewasa, dan upacara lainnya. Dan untuk menjaga kelestarian agama dipangarilah agama itu dengan berabagai macam aturan yamng tidak boleh dilanggar oleh penganutnya ( sesuatu yang tabu bagi individu), sehingga upcara-upacara keagamaan dapat diwariskan kepada generasi berikuntya .

2. Tipe Masyarakat Pra Industri sedang berkemebang

Masyarakat tipe ini lebih dikenal dengan istilah masyarakat dunia ketiga, yaitu suatu masa yang berada di antara tipe masyarakat terkebelakang dan nilai-nilai sakral dengan tipe masyrakat Industri yang sekuler. Adapun ciri-ciri masyarakat ini adalah jumlah anggota masyarakatnya tidak begitu besar, dan tidak terisolir, perubahan lebih cepat, daerahnya lebih luas serta tingkat perkembangan teknologi dan pengetahuan lebih tinggi daripada tipe pertama, Selanjutnya pembagian kerja telah mulai kelihatan, timbulnya stratifikasi sosial dalam masyarakt, adanya kemampuan tulis baca dikalangan masyarakat sampai tingkat tertentu. Masalah pertanian dan industri tangan adalah sarana utama untuk menopang ekonomi pedesaan dengan beberapa kota sebagai pusat perdagangannya. Kemudian kembaga-lembaga pemerintahan dan kehidupan ekonomi berkembang pesat yang mengarah kepada spesislisasi dalam keahliannya masing-masing

Dadang Kahmat menjelaskan bahwa; organisasi keagamaan yang biasanya menghimpun semua anggota, memberikan ciri-ciri khas kepada tipe ini, meskipun ia merupakan organisasi formal yang

12 Ibid, h. 52. 
terpisah dan berbeda serta memiliki tenaga yang proposional sendiri. Agama memberikan arti dan ikatan pada sistem nilai dalam tipe masyarakat ini. Akan tetapi masih pada saat yang sama, lingkungan yang sakral dan sekuler sedikit banyak masih dapat dibedakan. ${ }^{13}$

Dalam masyarakat tipe ini, agama mempunyai fungsi ganda, disatu sisi berfungsi sebagai pemersatu, dan di sisi lain agama sebagai pemecah belah, Kondisi masyarakat tipe ini disebabkan: Pertama, dalam masyarakat pra industri dan masyarakat yang sedang berkembang, dimana perangkat organisasi keagamaan dan struktur kekuatan politik bisa menimbulkan bentrok politik keagamaan dalam masyarakat. Benturan-benturan itu bisa dianggap sebagai usaha mempersatukan, karena benturan itu telah berfungsi menyatukan bersama masing-masing masyarakat. Kedua, timbulnya benturanbenturan yang meruncing antara kepentingan organisasi keagamaan dan organisasi politik, hal ini disebabkan masing-masing organisasi mempunyai cakupan wilayah masing-masing, struktur dan sikap dasar sendiri-sendiri. Sedangkan setiap organisasi menuntut kesetiaan anggotanya. Sehingga timbullah bentrokan diantara organisasi keagamaan dengan organiasasi pemerintahan. Sebagaimana kondisi dan peristiwa pada pilkada DKI Jakarta tahun 2017. kemudian organisasi memiliki bentuk dan obyek operasinya yang sama, sehingga menimbulkan benturan antara kedua porganiisasi tersebut. Secara umum, hal ini sering terjadi pada waktu pemilihan Presidien dan wakil Presiden, pemilihan Gubernur /Wakilnya dan Pemilihan Bupati/ wakilnya serta Pemilihan Wali Kota/Wakilnya.

Ketiga, masyarakat tipe ini semakin majemuk, perlawanan antara kelompok pertama dan kelompok yang datang belakangan mulai menurun. Kelompok terakhir datang dengan tatanan politik dan ekonomi baru, maka agama bisa tampil dengan pembaharuan yang bersifat kreatif. $^{14}$ Dalam pengamatan penulis, konteks masyarakat tipe ini menggambarkan kondisi Indonesia di akhir abad ke 20 yang dikenal dengan era reforemasi yang tampil dengan konsep-konsep baru dalam bidang pemerintahan, politik, ekonomi, masyarakat dan tatanan kehidupan baru daalam melanjutkan pembangunan

${ }^{13}$ Dadang Kahmat, Sosiologi Agama, Potret Agama dalam Dinamika Konflik, Pluralisme, dan Modern, Baandung: CV.Pustaaka Setia, Cet. I, 2010, h. 126.

${ }^{14}$ Elizabeth K. Nottigham, Op.Cit, h. 56-57 


\section{Tipe Masyarakat-Masyarakat Industri Sekuler}

Kehidupan masyarakat tipe ini sangat dinamik, kemajuan teknologi semakin berpengaruh dalam segala aspek kehidupan. Mareka semakin terbiasa menggunakan metode empiris berdasarkan pada penalaran, dan effesiensi dalam menanggapi berbagai masalah, akibatnya kehidupan keagamaan mendapat tantangan, karena lingkungan yang sekuler semakin melemahkan hal-hal yang berbentuk keagmaan atau nilai0nilai sakral, sehingga mempersempit ruanglingkup kepercayaan dan pengalaman agama, hilangnya kharismatik nilai-nilai humanistik dalam masyarakat.

Didalam masyarakat modern yang semakin kompleks, organisasi keagamaan terpecah-pecah dan bersifat majemuk. Keanggotaannya didasarkan pada prinsip organisasi-organisasi keagamaan tertentu, sehingga semakin melebarnya jurang pemisah antara nilai sekuler dan nilai sakral, selain itu tidak ada ikatan resmi antara organisasi keagamaan dengan organisasi pemerintah duniawi. Tetapi dalam pelaksanaannya mereka saling bekerjasama untuk mencapai tujuannya masing-masing. Namun organisasi-organisasi sekuler masih meminta bantuan pemuka agama pada acara-acara resmi kenegaraan. Begitu pula organisasi politik masih memakai simbol-simbol keagamaan tertentu dalam mencapai tujuannya. Dan ciri-ciri ini mempunyai implikasi-implikasi khusus bagi agama yang berfungsi ganda, yaitu di satu sisi agama sebagai pemersatu Di sisi lain agama sebagai pemecah belah, sehingga kekuatan sekulerisme semakin melemahkan nilai-nilai agama.

Mereka mengambil sikap toleransi terhadap perberdaan agama sebagai ciri khas dari masyarakat agamai. Akibat ketidakacuhan mereka dalam menghadapi pengaruh sistem nilai sekuler yang semakin berkembang; organisasi- organisasi keagamaan pun tidak lupa dari pengaruh sekulerisasi. Berbagai penganut organisasi keagamaan melaksanakan fungsi pemersatu bagi anggota kelompoknya yang sebagian besar anggotanya berasal dari kelas atau suku minoritas dalam masyarakat, pada kelompok ini agama memegang tugas rangkap, Nottingham menulis peran ganda yang dilakukan agama, yaitu: Pertama, agama menyatukan anggotanya 
akibat tersingkirkan atau terlantarkan dalam tatanan kehidupan sosial. Kedua, agama sebagai pembatas dan memecah-belah kelompok dan menghilangkan identitas. ${ }^{15}$

Dalam mensosialisasikan nilai-nilai agama, orang tua masih menyerahkan anak-anaknya pada kegiatan keagamaan sekolah Sabtu dan Minggu yang diadakan oleh gereja, dalam mendidik anak-anak, kebanyakkan orang tua di Amerika/ kota-kota lain masih beranggapan bahwa nilai-nilai keagamaan tradisional atau nilai-nilai serupa yang telah diperbaharui dengan versi baru merupakan landasan pembentukkan karakter yang dapat dibenar.

Selanjutnya Elizabeth menjelaskan bahwa dalam masyarakat tipe ini terdapat berbagai tipe penyesuaian yang lazim terhadap masalah keutuhan kepribadian dalam masyarakat industri modern. Pertama, kepribadian seseorang secara insklusif terintegrasi atas dasar nilai-nilai organisasi keagamamaan tertentu, dimana dia menjadi anggotanya. Kedua, pengintegrasian kepribadian yang baik melalui proses penggolongan (compartmentalization). Dia mampu menggambungkan yang bersifat konvesional dari apa yang disebut sekolah agama Sabtu dan Minggu dengan orientasi hidup sehari-hari terhadap nilai-nilai sekuler bertentangan, ${ }^{16}$ Untuk dapat memahamami antara yang diajarkan di sekolah Sabtu dan Minggu dengan realitas dalam masyarakt. mereka berusaaha memberikan interperetasi agar dapat beradaptasi dengan kenyataan yang ada dalam masyarakat, umpamanya; cintailah tetanggamu sebagaimana engkau mencintai dirimu sendiri. Dan ungkapan ini mengadung sifat solidaritas anakanak terhadap teman-teman, dan begitu pula ungkapan-ungkapan keagamaan lainnya.

\section{Agama Dalam Berbagai Aspek}

Agama termasuk suatu struktur institusional sosial yang penting bagi masyarakat dan turut mewarnai sistem sosial lainnya di dalam kehidupan manusia. Keberagamaan sesorang memiliki pengaruh yang kuat terhadap perilaku masyarakat, yang bersumber pada emosi keagamaan., maka ditemuilah berbagai persepsi

${ }^{15}$ Ibid, h. 54.

${ }^{16}$ Ibid, h 66. 
masyarakat terhadap agama. Kemudian setiap masyarakat mempunyai pola dan tingkah laku keagamaan yang berbeda Agama sebagai struktur sosial dalam masyarakat memiliki beberapa aspek keagamaan manusia, yaitu :

\section{Aspek Kepercayaan Keagamaan}

Kepercayaan keagamaan merupakan sesuatu yng sangat penting bagi penganutnya, karena kepercayaan keagamaan memiliki aspek kognitif atau intelektualitas untuk dapat memahami dan menyakini kepercayaannya, disebabkan agama membentuk cara pandang seseorang tentang dunia, Persepektif itu akan mempengaruhi cara pandang indvidu sekaligus akan mempengaruhi seseorang dalam bertindak. Bernard Raho menulis bahwa Dalam masyarakat modern, ada semacam kecenderungan bahwa orang mempraktekan iman semata-mata sebagai suatu pendapat atau cara pandang yang bertentangan dengan pengetahuan yang didasarkan pada fakta empiris. ${ }^{17}$

Sebenarnya kepercayaan agama bukanlah sesuatu yang abstrak, dan mempunyai relevansi dengan kehidupan sehari-hari. Namun, orang sering menggunakan kepercayaan-kepercayaannya itu di dalam melakukan pilihan-pilahan dalam hidup, menafsirkan suatu peristiwa atau kejadian-kejadian yang luar biasa, dan merencanakan tindakan-tindakan tertentu melalui pengetahuan mitologi.

Kepercayaan dalam beragama mengambil bentuk kegiatankegiatan intelektualitas dalam dua macam Sebagaimana dijelakan Thomas F. O'dea bahwa; Kita dapat membagi pengungkapan intelektual dari agama kedalam dua bagian utama, yakni mitos dan rasional ${ }^{18}$. Pertama, mitos adalah bentuk ungkapan intelekutal yang primordial dari berbagai sikap dan kepercayaan keagamaan Mitos berhubungan erat dengan perasaan dalam dari seorang individu. Ernst Cassairer, sarjana dan pengikut simbolisme menyatakan bahwa Mitos berasal dari emosi dan latar belakang emosionalnya mengilhami semua hasilnya dengan warnanya yang khusus. Manusia

17 Bernard Raho, Agama Dalam Perpsektif Sosiologi, Jakarta : Penerbit Obor, Cet. I, 2003, h. 13.

18 Thomas F'dea, The Sociologi Of Religion, Terj. Tim.YASOGAMA, Yogyakarta: CV. Rajawali Yayasan Solidaritas Gajah Mada, Cet. I, 1985, h. 79. 
primitive bukan kurang memiliki kesanggupan untuk memahami berbagai perbedaaan empiris dari sesuatu. Tetapi dalam konsepsinya tentang alam dan kehidupan semua perbedaaan ini dihilangkan oleh prasaan yang lebih kuat. ${ }^{19}$ Mitos juga merupakan jenis pernyataan manusia yang kompleks, merupakan pernyataan yang dramatis, bukan hanya sebagai pernyataan yang rasional.

Kedua, dalam pengalaman manusia, disamping itu mitos berkenaan dengan cara-cara pemahaman bentuk pemikiran dan metode penjelasan lainnya. Dihubungkan dengan kontak kebudayaan antara berbagai di masyarakat ke dalam strata dengan gaya dan pengalaman yang berbeda. Para sarjana dan intelektual mengkatogorikan perkembangan ini kedalam beberapa tahap . August Comte berbicara tentang "Hukum Tiga Tahap" yang terdiri dari, tahap keagamaan, tahap metafisik (atau teological), tahap positivisme. Selanjutnya, Comte mengartikan tahapan keagamaan (tahap teological) sebagai priode pandangan dan pemahaman mistis; tahap metafisik, merupakan priode dimana yang digunakan untuk mengorganisasi dunia pengalaman bukannya katogori rasional subjektif, tetapi katagori dan konsep yang abstrak; sedangkan tahap positif merupakan periode dimana dikembangkan model pemahaman ilmiah dan pembentukan konsep modern. ${ }^{20}$ Demikanlah langkahlangkah yang dilalui pemikir dalam membicarakan kepercayaan keagamaan

\section{Aspek Ritus-Ritus Keagamaan}

Dalam agama, upacara ritual keagamaan biasa dikenal dengan istilah ibadat, kebaktian, berdoa, atau sembahyang. Justru itu setiap agama mengajarkan berbagai macam bentuk kegiatan-kegiatan ibadat kepada penganutnya, sesuai dengan momen-momen pelaksanaannya.. Bagi Durkheim, upacara-upacara ritual dan ibadah adalah untuk meningkatkan solidaritas, untuk menghilangkan perhatian kepada kepentingan pribadi. Selanjutnya Durkheim menciutkan makna yang terkandung dalam upacara keagamaan kepada keutuhan masayarkat atau solidaritas sosial. ${ }^{21}$ Kepercayaan-

19 Ibid, h. 80.

20 Ibid, h. 82.

21 Bustanuddin Agus, Agama Dalam Kehidupan Manusia, Pengantar Antropologi Agama, Jakarta: PT. Raja Grafindo Persada, 2000, h. 102. 
kepercayaan dan ritus-ritus merupakan simbol-simbol yang mempersatukan kelompok sekaligus berfungsi untuk meningkatkan kesatuan dan solidaritas kelompok-kelompok dalam suatu agama

Ritus-ritus keagamaan merupakan salah satu bentuk ungkapan kepercayaan keagamaan Dengan melaksanakan ritus-ritus keagamaan, berarti kelompok-kelompok keagamaan memperbarui kembali komitmen, rasa persatuan, mmemperkuat kepercayaan di antara mereka, disamping itu anggota kelompok semakin mengindentifikasi diri dengan anggota-anggota kelompok dan tujuantujuan kelompok tersebut. Bernard menegaskan bahwa sebuah tindakan keagamaan disebut sebagai ritus keagamaan bukan hanya karena isi, tindakan, dan waktu-waktu ritus itu, melainkan karena arti atau makna yang diberikan oleh kelompok keagamaan bersangkutan. $^{22}$ Kondisi ritus seperti ini dicontohkan bahwa berpuasa pada bulan Ramadhan bagi orang Islam akan memberikan sifat sabar, tenang dan sebagainya, karena didasarkan pada keyakinan bahwa puasa itu adalah perintah Allah. Dan akan berbeda arti dan maksud puasa yang dilakukan sehari-hari, tanpa ada rasa kepercaayaan keagamaan, niscaya perbauatnnnya itu tidak mempengaruhi kehidupannya, karena puasa itu tidak didasarkan pada kepercayaan kegamaan.

Ritus-ritus keagamaan yang benar-benar diungkapkan di dalam kepercayaan memiliki kekuatan yang dahsyatnya dirasakan oleh pemeluknya. Kalimat-kalimat dalam upacara keagamaan dapat membangkitkan rasa hormat, kagum pada diri pemeluknya. Salah satu pentingnya ritus adalah memperkuat keyakinan terhadap adanya dunia yang gaib dan memberikan cara-cara pengungkapan emosi keagamaan secara simbolik.

3. Aspek Simbol-Simbol Keagamaan

Simbol merupakan salah satu unsur yang sangat penting dalam kehidupan beragama, karena berkaitan erat dengan yang suci, namun ritus-ritus itu tidak dapat dilakukan tanpa adanya simbolsimbol. Secara sederhana simbol berarti segala sesuatu yang mengandung arti tertentu yang dikenal dan difahami oleh anggota-

22 Bernard Raho, Op.Cit, h. 13. 
anggota suatu kelompok masyarakat. Simbol itu tidak ada artinya pada seseorang bila artinya tidak diberikan oleh masyarakat pendukungnya, maka secara sederhana dapat dikatakan bahwa kepecayaan keagamaan itu merupakan strukur sosial dalam masyarakat. Inti emosi keagamaan tidak dapat diekspresikan, bila tidak ada simbol-simbol tertentu, maka untuk itu para ahli berupaya unrtuk membuat perkiraan-perkiraan yang bersifat simbolik untuk dapat difahami para anggotanya.

Simbol-simbol diartikan lambang-lambang yang dapat mengekspresikan jiwa individu yang dapat bersatu dengan Tuhannya. Elizabeth menjelaskan bahwa ,... Lambang-lambang tersebut sepanjang sejarah dan juga sampai sekarang merupakan pendorong-pendorong yang paling kuat bagi timbulya perasaan manusiawi. Karena itu tidak sukar untuk difahami bahwa dimilikinya lambang bersama merupakn cara yang sangat efektif untuk mempererat persatuan di antara pemeluk (agama) di dunia ini. ${ }^{23}$

Suatu simbol keagamaan akan memperkuat rasa persaudaraan dan persatuan dalam suatu kelompok. Bernard menulis bahwa Simbol-simbol keagamaan itu membangkitkan perasaan keterikatan dan kesatuan pada anggota-anggota pemeluk agama yang sama. Memiliki simbol-simbol yang sama merupakan cara yang efektif untuk semakin memperkuat rasa persatuan di dalam kelompok pemeluk $^{24}$

Dengan demikian, simbol-simbol yang terdapat dalam agama merupakan sesuatu yang penting dalam kehidupan beragama bagi penganutnya, karena simbol-simbol itu menghubungkan individu untuk mengekspresikan dan relasinya dengan yang bersifat transcendent.

\section{Aspek Pengalaman Keagamaan}

Pada dasarnya pengalaman keagamaan itu bersifat pribadi dan subjektif, dan ahli psikologi agama mengatakan pengalaman agama (religious experience) adalah unsur perasaan dalam kesadaran agama, yaitu perasaan yang membawa seseorang kepada keyakinan yang

23 Elizabeth K,Nottingam, Religion And Society, ter, Adbul Muis Naharong, (Jakarta : CV. Rajawali, Cet. I, 1985), h. 17.

24 Ibid, h. 15. 
dihasilkan oleh tindakan (amaliah). ${ }^{25}$ Ketika berhubungan dengan yang suci para pemeluk suatu agama berusaha untuk mengungkapkan pengalaman keagamaan itu melalui doa, meditasi, beribadah, menari dan bernyanyi. Pengalaman-pengalaman keagamaan bersifat pribadi, tetap mempunyai elemen-elemen sosial bagi masyarakat, kemudian dari sisi inilah lahir istilah teologi sosial dan tasawuf sosial, karena elemen-elemen tersebut mempengaruhi seorang dalam menginterpretasikan pengalaman personal.

Pengalaman keagamaan yang dialami oleh seseorang akan berbeda dengan pengalaman keagamaan yang dilakukan oleh orang lain sesuai dengan kepercayaan keagamaannya. Bernard menulis bahwa; isi dari pengalaman religius itu berbeda-beda. Di dalamnya bisa terdapat pengalaman-pengalaman yang menggembirakan seperti damai, harmonis, sukacita, dan rasa aman. Namun, dipihak lain pengalaman-pengalaman keagamaan itu bisa menghasilkan teror, ketakutan, dan kecemasan. Sementara itu, isi dan pengalaman keagamaan itu sangat tergantung pada kepercayaan para pemeluk tentang apa yang dihadapinya. ${ }^{26}$

Setiap pengalaman keagamaan yang dialami oleh individu mempunyai hubungan dengan kekuasaan atau kekuatan yang suci itu, sehingga menimbulkan interpretasi-interpretasi. Bila individu mengalami perasaan aman tenteram dalam hidupnya, menandakan individu merasa dilindungi oleh yang suci itu, Sebaliknya, bila indvidu merasa ketakutan, resah, gelisah dan sebagainya dalam hidup berarti individu mendapat hukuman oleh kekuatan yang suci itu, dan fenomena-fenomena ini yang sering melanda masyarakat agama

Masyarakat modern umumnya tidak mengakui kebenaran pengalaman-pengalaman mistik (agama) mereka mementingkan pada pemikiran rasional dan objektif empiris. Karena pengalamanpengalaman keagamaann itu adalah sesuatu yang sangat bersifat subjektif yang sulit diuji kebenarannya dengan menggunakan pendekatan-ilmiah. Dan bukan pula tugas seseorang sosiologi agama untuk menilai benar atau salah pengalaman keagamaan seseorang

25 Zakiah Daradjat, Ilmu Jiwa Agama, Jakarta: Bulan Bintang, XIII, 1991, h. 4 .

26 Bernard Raho, Op.Cit, h. 16. 


\section{Aspek Masyarakat Agama}

Masyarakat agama merupakan bentuk kehidupan individu yang saling berinteraksi, bergaul cukup lama dan menganut kepercayaan atau agama sebagai dasar hidup dan kehidupannya serta membentuk suatu kebudayaan Aspek masyarakat agama sangat erat hubungannya dengan aspek simbol-simbol keagamaan, karena simbol-simbol keagamaan itu membangkitkan perasaan keterikatan dan kesatuan para anggota-anggota pemeluk agama yang sama. memiliki simbol-simbol yang sama sebagai cara yang efektif untuk semakin memperkuat rasa persatuan di dalam kelompok pemeluk agama bersangkutan.

Kepercyaan-kepecayaan dan pengalaman keagamaan berfungsi sebagai pemersatu masyarakat agama bersangkutan, mengakibatkan timbulnya komunitas-komunitas agama dalam masyarakat, menurut Elizabeth bahwa hal ini terjadi apabila keanggotaan kelompok-kelompok semacam itu sebagian besar berasal dari kelas atau suku minoritas dalam masyarakat yang lebih luas.. Dalam kondisi ini kenyakinan-kenyakinan dan pengalamanpengalaman keagamaan tersebut melaksanakan tugas rangkap; pertama sebagai pusat "kebersamaan" bagi kelompok-kelompok yang tersingkirkan atau diterlantarkan dalam tatanan sosial yang semakin menghilangkan kepribadian, dan kedua, sebagai batas-batas orientasi yang mungkin bagi kecenderungan yang memecah belah ${ }^{27}$ disamping itu, agama tidak hanya menjamin stabilitas sosial, tetapi kadang-kadang juga mendukung konservasime dalam masyarakat.

Masyarakat atau komunitas suatu agama bisa terorganisasi atau terlembaga secara formal dan informal. Organisasi keagamaan yang berbentuk formal bisa ditemukan di dalam masyarakat dengan membentuk organisasi keagamaan, misalnya organisasi keagamaan Islam, Keristen, Katolik, Budha, dan organiasi keagamaan Hindu. Dengan adanya kelompok atau penganut agama terbentuklah masyarakat agama dan melalui masyarakat itu aspek kepercayaan, aspek ritus-ritus keagamaan, simbol-simbol keagamaan, pengalaman

${ }^{27}$ Elizabeth K. Nottingham, Loc.Cit. 
keagamaan dan masyarakat keagamaan dapat dilestarikan dalam masyarakat.

\section{E. Penutup}

Agama merupakan suatu kekuatan yang paling dirasakan berpengaruhnya di dalam kehidupan manusia. Agama mempengaruhi manusia dalam segala segi aspek kehiduipan. Kepecayaan-kepercayaan dan nilai-nilai agama memberikan motivasi kepada manusia dalam bertingkah laku dan mempengaruhi kelompok di dalam menata kehidupan bersama. Perspektif orang yang agamais mendasarkan pada keimanan, sedangkan perspektif sosiolog didasarkan pada data empiris Dalam masyarakat agama, bentuk kepercayaan merupakan sesuatu yang bersifat sentral dalam kehidupan mereka, dan mereka menghubungkannya dengan sesuatu yang bersifat transcendental dalam hidup ini.

Agama menawarkan hubungan melalui pemujaan dan berbagai bentuk upacara ibadah, karena itu memberikan rasa emosional bagi rasa aman baru dan identitas yang lebih kuat ditengah-tengah ketidakpastian dan ketidakmungkinan bagi kehidupan manusia, Walaupun nilai dan kadar kepecayaannya itu berbeda-beda dalam berbagai tipe masyarakat dan nilai-nilai sakral. Namun agama sangat berpengaruh bagi penganutnya. Pertama, pengaruh agama terhadap masyarakat, seperti ysng terlihat dalam pembentukan, pengembangan, dan penentuan kelompok keagamaan spesifik yang baru. Kedua, pengaruh masyarakat terhadap agama. Beberapa faktor sosial yang memberikan nuansa dan keberagaman perasaan dan sikap keagamaan yang terdapat dalam suatu lingkungan atau kelompok sosial tertentu

Agama termasuk suatu struktur institusional sosial yang penting bagi masyarakat yang turut mewarnai sistem sosial lainnya. Keberagamaan memiliki pengaruh yang kuat terhadap perilaku masyarakat yang bersumber pada emosi keagamaan. Maka timbullah berbagai bentuk persepsi masyarakat terhadap pola dan tingkah laku keagamaan yang berbeda Agama sebagai struktur sosial memiliki beberapa aspek penting dalam pembinaan dan pengembangan 
Syaiful Hamali

penganutnya, diantaranya adalah: Aspek kepercayaan keagamaan, ritus-ritus keagamaan, simbol-simbol keagamaan, pengalaman keagamaan, dan masyarakat agama . 


\section{Daftar Pustaka}

Bernard Raho SVD, Agama Dalam Perspektif Sosiologis, Jalarta: Penerbit Obor, Cet. I, 2003.

Bustanuddin Agus, Agama Dalam Kehdiupan Manusia, Pengantar

Antropologi Agama, Jakarta: PT. Raja Rafindo Persada, 2000.

Dadang Kahmad, Sosiologi Agama, Bandung: PT.Remaja Rosdakarya, Cet.V, 2009.

Elizabeth K,Nottingam, Religion And Society, ter, Adbul Muis Naharong, Jakarta : CV. Rajawali, Cet. I, 1985.

Hendro Puspito, D, Sosiologi Agama, Jakarta: Gunung Mulia, Cet. IV, 1988.

Kiki Muhamad Hakiki dan Zaenal Muttaqien, Konflik dan Integrasi Sosial (Telaab Buku A. Malik MTT berjudul "Pura dan Masjid; Konflik dan Integrasi Pada Suku Tengger Jawa Timur), AlAdYaN/Vol. IX, N0. 2/Juli-Desember/2014.

Tim ICCE UIN Jakarta, Pendidikan Kewargaan (civic Education) Demokrasi, Hak Asasi manusia \& Masyarakat Madani, Jakarta : Pernada Media, Edisi Revisi, 2003.

Thomas F'dea, The Sociologi Of Religion, Terj. Tim.YASOGAMA, Yogyakarta: CV. Rajawali Yayasan Solidaritas Gajah Mada, Cet. I, 1985.

Nurcholis Madjid, Kehampaan Spiritual Masyarakat Modern, Jakarta : Penerbit Mediacita, 2000.

--------, Civil Society Versi Masyarakat Madani , Bandung: Pustaka Hidayah, 1990.

M.Dawam Raharjo, Masyarakat Madani: Agama Kelas Menengah dan Perubahan Sosial,, Jakarta: LP3ES.

Zakiah Daradjat, Ilmu Jiwa Agama, Jakarta: Bulan Bintang, XIII, 1991. 
Syaiful Hamali 